\title{
Bushing Device
}

National Cancer Institute

\section{Source}

National Cancer Institute. Bushing Device. NCI Thesaurus. Code C49853.

A cylindrical metal sleeve designed to reduce the friction of a rotating shaft. 